\title{
Adiponectin regulates the malignant biological behavior of endometrial cancer cells via AMPK/mTOR signal pathway
}

\author{
Li Jin ${ }^{1}$, Xiumei Feng ${ }^{2}$, Dan Luo ${ }^{2 *}$ \\ ${ }^{1}$ Department of Gynecology, Jingmen No. 1 People's Hospital, Jingmen, ${ }^{2}$ Department of Gynecology, Jingmen No. 2 People's \\ Hospital, Jingmen, PR China \\ *For correspondence: Email: jcfu10@163.com
}

Sent for review: 17 December 2020

Revised accepted: 24 April 2021

\begin{abstract}
Purpose: To study the mechanism by which adiponectin regulates the malignant biological behavior of endometrial cancer cells.

Methods: RL95-2 cells were cultured and re-suspended in complete medium. A preliminary study showed that adiponectin $(20 \mu \mathrm{g} / \mathrm{mL})$ has the most inhibitory effect on cellular proliferation. The cells were divided into control group, $20 \mu \mathrm{g} / \mathrm{mL}$ adiponectin group, and $20 \mu \mathrm{g} / \mathrm{mL}$ adiponectin $+10 \mu \mathrm{mol} / \mathrm{L}$ AMPK inhibitor group, with 4 repeat wells set up for each group. Cell proliferation, apoptosis, invasion and migration ability, as well as the expression levels of MMP-9, Bcl-2, $p-A M P K, p-m T O R$ and $p-4 e b p 1$ were determined using standard procedures.

Results: Cell proliferation was significantly higher in the $20 \mu \mathrm{g} / \mathrm{mL}$ adiponectin group than in the 10 $\mu \mathrm{g} / \mathrm{mL}$ adiponectin group $(p<0.05)$. Relative to the control group, apoptosis and $p$-AMPK expression level in the $10 \mu \mathrm{g} / \mathrm{mL}$ adiponectin group increased, while cell invasion and migratory potential, as well as expression levels of MMP-9, Bcl-2, p-mTOR and p-4ebp1 declined significantly $(p<0.05)$. The apoptosis and expression level of $p$-AMPK in the $20 \mu \mathrm{g} / \mathrm{mL}$ adiponectin $+10 \mu \mathrm{mol} / \mathrm{L}$ AMPK inhibitor group decreased, while cell invasion, migratory ability, and amounts of MMP-9, Bcl-2, $p-m T O R$ and $p-$ 4 ebp 1 were elevated, relative to the $20 \mu \mathrm{g} / \mathrm{mL}$ adiponectin group $(p<0.05)$.

Conclusion: Adiponectin promotes apoptosis of endometrial cancer cells via AMPK/mTOR signaling pathway, and inhibits cell proliferation, invasion and migration. Thus, adiponectin has the potential to exert anti-tumor effect in humans.
\end{abstract}

Keywords: Adiponectin, AMPK/mTOR, Endometrial cancer, Biological behavior, Mechanism

\begin{abstract}
This is an Open Access article that uses a fund-ing model which does not charge readers or their institutions for access and distributed under the terms of the Creative Commons Attribution License (http://creativecommons.org/licenses/by/4.0) and the Budapest Open Access Initiative (http://www.budapestopenaccessinitiative.org/read), which permit unrestricted use, distribution, and reproduction in any medium, provided the original work is properly credited.
\end{abstract}

Tropical Journal of Pharmaceutical Research is indexed by Science Citation Index (SciSearch), Scopus, International Pharmaceutical Abstract, Chemical Abstracts, Embase, Index Copernicus, EBSCO, African Index Medicus, JournalSeek, Journal Citation Reports/Science Edition, Directory of Open Access Journals (DOAJ), African Journal Online, Bioline International, Open-J-Gate and Pharmacy Abstracts

\section{INTRODUCTION}

Malignant tumor is a disease that has a serious impact on human health and life. Some scholars believe that the biological behaviors of malignant tumors are the result of multiple factors and intergenic interactions [1]. Endometrial cancer is the most common malignant tumor of the female reproductive tract. With improvement in living standards and extensive use of hormones, the incidence of endometrial cancer is increasing year by year, and gradually tending towards the younger generation [2]. At present, surgery combined with chemoradiotherapy is one of the main methods for treatment of this disease, but some patients still have poor prognosis after 
receiving a series of treatments. Therefore, it will be of great significance to elucidate the pathogenesis of endometrial cancer and to find relevant diagnostic and treatment methods for the disease so as to improve the prognosis of patients.

Adiponectin, a protein hormone secreted by fat cells, is the only adipose-derived cytokine that has protective effects on humans. Through its receptor, adiponectin activates two pathways, cyclic adenosine monophosphate acid (CAMP/PKA) and AMP-activated protein kinase (AMPK), resulting in a variety of regulating effects on cellular function [3]. Studies have found that adiponectin is significantly correlated with gastric cancer, breast cancer, prostate cancer, endometrial cancer and other malignant tumors, but the mechanism associated with this process is still unclear [4]. The purpose of this study was to investigate the mechanism involved in adiponectin-induced regulation of the biological behavior of endometrial cancer cells.

\section{EXPERIMENTAL}

\section{Cells}

Human endometrial cell line RL95-2 cells were obtained from Shanghai Fusheng Industrial Co. Ltd.

\section{Main instruments and reagents}

The major instruments and reagents used, and their sources (in brackets) were: carbon dioxide incubator (Shanghai Yiheng Scientific Instrument Co. Ltd, Model: DHP-9272); electric thermostatic water bath box (Jiangsu Zhengji Instrument Co. Ltd, Model: DK-600B); real-time fluorescence quantitative PCR instrument (Model: VIIA 7); Biological microscope (Shun-Yu Optical Technology Co. Ltd, Model: EX31); cryogenic high-speed centrifuge (Changzhou Jintan Lepu Instrument Co. Ltd, Model: TGL16G); fetal bovine serum (Shanghai Huiying Biotechnology Co. Ltd); rabbit anti-human AMPK monoclonal antibody (Shanghai Kemin Biotechnology Co. Ltd); rabbit anti-human mTOR monoclonal antibody (Shanghai Hengfei Biotechnology Co. Ltd), and AMPK inhibitor (Shanghai Xingyuan Ruimin Biological Engineering Co. Ltd).

\section{Cell culture}

The RL95- 2 cells were cultured in a $5 \%$ carbon dioxide cell incubator at $37^{\circ} \mathrm{C}$ with $10 \%$ fetal bovine serum. When the cells grew to about 85 $\%$ confluence, they were sub-cultured and digested with an appropriate amount of trypsin.
When the cells shrunk and the intercellular space was enlarged, $4 \mathrm{ml}$ of medium containing serum was added to terminate digestion, and the cells were gently blown away from the bottle wall to form a single-cell suspension. Then, the cells were diluted 1:2 with culture medium and inoculated into a new culture flask.

\section{Determination of cell proliferation}

Changes in cell proliferation were measured using CCK-8 method. The cells were resuspended in complete medium and inoculated into 96-well plates, with $100 \mu \mathrm{L}$ of 1000 cells per well, and 4 repeated wells were set up in each group. Two doses of adiponectin, i.e., 10 and 20 $\mu \mathrm{g} / \mathrm{mL}$, were used, and the cells were cultured for $48 \mathrm{~h}$. Untreated cells served as control. Thereafter, CCK-8 $(20 \mu \mathrm{L})$ was put in each well, and culturing was done for another $2 \mathrm{~h}$. The absorbance of each well was read at $570 \mathrm{~nm}$ in a microplate reader.

The results showed that adiponectin at a level of $20 \mu \mathrm{g} / \mathrm{mL}$ produced the most obvious inhibitory effect on cell proliferation. Therefore, this level of adiponectin was used in subsequent experiments.

The cells were assigned to control, $20 \mu \mathrm{g} / \mathrm{mL}$ adiponectin and $20 \mu \mathrm{g} / \mathrm{mL}$ adiponectin +10 $\mu \mathrm{mol} / \mathrm{L}$ AMPK inhibitor groups, with 4 repeated wells set up in each group.

The CCK-8 method was applied for determination of changes in cell proliferation in each group of cells.

\section{Evaluation of apoptosis}

Apoptotic changes were determined flow cytometrically in each group. Cell suspension was re-suspended in $100 \mu \mathrm{L}$ of binding buffer, followed by addition of $5 \mu \mathrm{L}$ of PE Annexin $V$ and 7-AAD, incubating away from light at laboratory temperature for $15 \mathrm{~min}$, and adding $200 \mu \mathrm{L}$ of binding buffer. Apoptosis was analyzed after $1 \mathrm{~h}$ using flow cytometry.

\section{Assessment of cell migration}

Transwell assay was used to measure changes in cell migration ability in each group of cells. Cell suspension $(200 \mu \mathrm{L})$ was put in the upper Transwell compartment, while $600 \mu \mathrm{L}$ of $10 \%$ FBS was put in the lower compartment, followed by culturing at $37^{\circ} \mathrm{C}$ for $24 \mathrm{~h}$. Then, the chamber was taken out and rinsed with phosphate buffer. A cotton swab was used to wipe off unmigrated cells, and the chamber was fixed. Then, the 
fixative was removed and dried naturally. Crystal violet dye was added to the cells, followed by rinsing with phosphate buffer. Five fields of vision were randomly selected and observed under a light microscope.

\section{Determination of cell invasion}

Transwell assay was used to determine changes in cell invasion ability in each group of cells. Serum-free culture medium and $100 \mu \mathrm{L}$ of Matrigel diluent were added to the upper chamber. The subsequent procedures were similar to those in cell migration study.

\section{Western blot assay}

The expression levels of MMP-9, Bcl-2, p-AMPK, p-mTOR and p-4ebp1 in each group of cells were determined using western blot assay. Cells in each group were washed in pre-cooled phosphate buffer, and lysed with lysis buffer. The lysates were centrifuged, and the protein contents of the supernatants were determined with BCA method. Absorbance was read at 560 $\mathrm{nm}$, and the readings were used to calculate the protein contents.

Thereafter, the proteins were subjected to SDSPAGE and electroblotting onto PVDF membranes which were subsequently blocked by incubation with non-fat milk solution. Then, the membranes were incubated with appropriate primary antibodies for $12 \mathrm{~h}$ at $4{ }^{\circ} \mathrm{C}$. Then, the PVDF membranes were treated with horseradish peroxidase-labeled anti-rabbit $2^{\circ}$ antibody for $1 \mathrm{~h}$. The membranes were then evenly covered with developer solution, and the Image-Lab software was used for determination of gray value. Multiple tests were carried out for each group, and the expression levels were recorded.

\section{Statistical analysis}

Data are expressed as mean \pm standard deviation (SD). Two-group comparison was done with independent sample $t$-test, while mean values of single factor and multiple samples were used for comparison among multiple groups. All statistical analyses were carried out using SPSS 21.0 software. Values of $p<0.05$ indicated statistically significant differences.

\section{RESULTS}

\section{Changes in cell proliferation}

Cell proliferation capacity of the $10 \mu \mathrm{g} / \mathrm{mL}$ adiponectin group was significantly reduced, relative to the control group, and proliferative capacity in $20 \mu \mathrm{g} / \mathrm{mL}$ adiponectin group was markedly lower than that in the low-dose adiponectin group. However, cell proliferation capacity in the $20 \mu \mathrm{g} / \mathrm{mL}$ adiponectin $+10 \mu \mathrm{mol} / \mathrm{L}$ AMPK inhibitor group was markedly increased, relative to high-dose adiponectin group ( $p<$ 0.05). These results are shown in Table 1.

Table 1: Changes in cell proliferation ability

\begin{tabular}{ll}
\hline Group & Absorbance \\
\hline Control & $0.88 \pm 0.02$ \\
$10 \mu \mathrm{g} / \mathrm{mL}$ adiponectin & $0.34 \pm 0.02^{\mathrm{a}}$ \\
$20 \mu \mathrm{g} / \mathrm{mL}$ adiponectin & $0.26 \pm 0.03^{\mathrm{ab}}$ \\
$20 \mu \mathrm{g} / \mathrm{mL}$ adiponectin + & $0.67 \pm 0.02^{\mathrm{abc}}$ \\
$10 \mu \mathrm{mol} / \mathrm{L}$ AMPK inhibitor & 637.14 \\
$F$ & $<0.001$ \\
$P$-value &
\end{tabular}

Data are presented as mean \pm SD. ${ }^{a} P<0.05$, vs control; ${ }^{b} p<0.05$, vs low-dose adiponectin; ${ }^{c} p<0.05$, vs high-dose adiponectin

\section{Cell apoptosis}

The \% apoptosis of the $20 \mu \mathrm{g} / \mathrm{mL}$ adiponectin group was significantly increased, relative to the control group. However, \% apoptosis in the 20 $\mu \mathrm{g} / \mathrm{mL}$ adiponectin $+10 \mu \mathrm{mol} / \mathrm{L}$ AMPK inhibitor group was significantly decreased, relative to high-dose adiponectin group $(p<0.05)$. These results are shown in Table 2.

Table 2: Cell apoptosis

\begin{tabular}{|c|c|}
\hline Group & $\begin{array}{l}\text { Cell apoptosis } \\
\text { rate }(\%)\end{array}$ \\
\hline Control & $5.09 \pm 0.44$ \\
\hline $20 \mu \mathrm{g} / \mathrm{mL}$ adiponectin & $18.06 \pm 0.78^{a}$ \\
\hline $\begin{array}{l}20 \mu \mathrm{g} / \mathrm{mL} \text { adiponectin + } \\
10 \mu \mathrm{mol} / \mathrm{L} \text { AMPK inhibitor }\end{array}$ & $6.95 \pm 0.85^{\mathrm{ab}}$ \\
\hline F & 387.16 \\
\hline$P$-value & $<0.001$ \\
\hline
\end{tabular}

\section{Cell invasion and migration capacity}

Cell invasion and migration capacity were significantly decreased in low-dose adiponectin group, relative to control, but were markedly higher in the $20 \mu \mathrm{g} / \mathrm{mL}$ adiponectin $+10 \mu \mathrm{mol} / \mathrm{L}$ AMPK inhibitor group than in cells exposed to adiponectin at a dose of $20 \mu \mathrm{g} / \mathrm{mL}(p<0.05)$. These results are shown in Figure 1 and Figure 2, and Table 3.

\section{Expression levels of MMP-9, Bcl-2, p-AMPK, $\mathrm{p}$-mTOR and $\mathrm{p}-4 \mathrm{ebp} 1$}

As presented in Table 4 and Figure 3 , the expression level p-AMPK in the $10 \mu \mathrm{g} / \mathrm{mL}$ adiponectin group was significantly increased, 
while those of MMP-9, Bcl-2, p-mTOR and p4ebp1 were markedly decreased, when compared with the control group ( $p<0.05)$. In contrast, relative to high-dose adiponectin group, the expression level of p-AMPK in the $20 \mu \mathrm{g} / \mathrm{mL}$ adiponectin + $10 \mu \mathrm{mol} / \mathrm{L}$ AMPK inhibitor group was markedly decreased, and the expressions of MMP-9, Bcl-2, p-mTOR and p-4ebp1 were upregulated $(p<0.05)$.

\section{DISCUSSION}

Endometrial carcinoma is an epitheliogenic malignant tumor derived from the endometrium or uterus. According to statistics, endometrial cancer accounts for about $7 \%$ of female systemic malignant tumors, and about $25 \%$ of female reproductive tract malignant tumors, making it one of the three major malignant tumors of the female reproductive tract [5]. Based on the clinical characteristics of endometrial carcinoma and biological types, it can be divided into type I and type II. The type I accounts for about $80 \%$ of cases, and it is associated with lower degree of malignancy and better prognosis than type II. Thus, type II has higher degree of malignancy and poorer prognosis [6]. The main clinical treatment strategies for endometrial cancer are surgery, chemoradiotherapy and hormone therapy. For early-stage patients, surgery results in good curative effect. In contrast, there is high degree of post-surgery recurrence in advanced-stage patients. Chemoradiotherapy is associated with toxic side effects, and it easily leads to drug resistance which makes treatment difficult. Therefore, it will be of great clinical benefit to find a treatment method with less toxic side effects and higher safety.

Adiponectin is considered an adipocytokine with therapeutic potential. It was first identified in 1995 in pre-adipocytes of mice as a factor related to obesity, insulin resistance and diabetes [3]. Studies have confirmed that adiponectin is a protective and adipose-derived cytokine which activates two different adiponectin receptors, namely adiponectin receptor 1 and adiponectin receptor 2 [7].

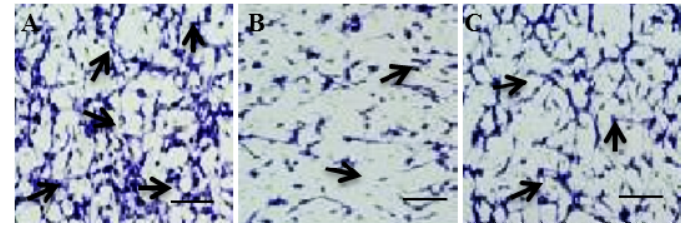

Figure 1: Cell invasion capacity. A: control group; B: high-dose adiponectin group; C: $20 \mu \mathrm{g} / \mathrm{mL}$ adiponectin $+10 \mu \mathrm{mol} / \mathrm{L}$ AMPK inhibitor group

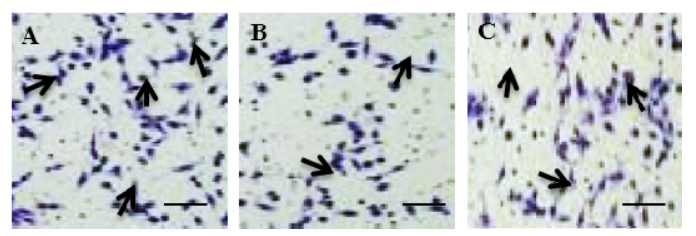

Figure 2: Cell migration in each group of cells. A: control group; B: high-dose adiponectin group; C: 20 $\mu \mathrm{g} / \mathrm{mL}$ adiponectin $+10 \mu \mathrm{mol} / \mathrm{L}$ AMPK inhibitor group

Table 3: Cell invasion and migration capacity

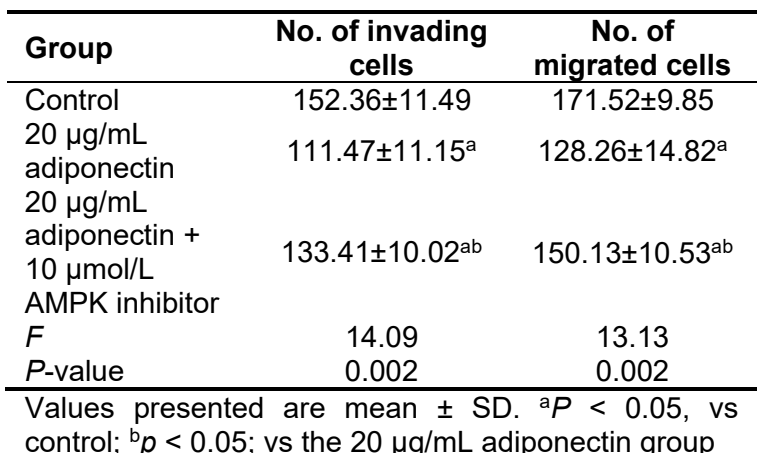

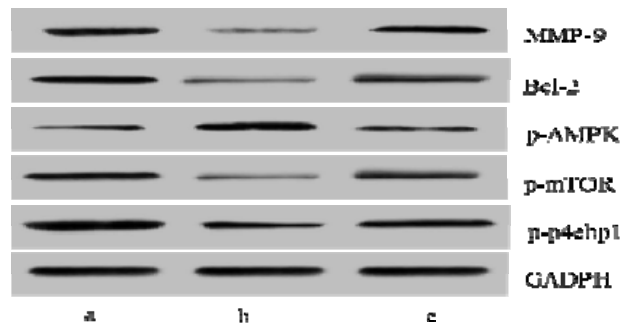

Figure 3: Expression levels of MMP-9, Bcl-2, pAMPK, p-mTOR and p-4ebp1. A: control group; B: high-dose adiponectin group; C: $20 \mu \mathrm{g} / \mathrm{mL}$ adiponectin $+10 \mu \mathrm{mol} / \mathrm{L}$ AMPK inhibitor group

Table 4: Expression levels of MMP-9, Bcl-2, p-AMPK, p-mTOR and p-4ebp1 in each group

\begin{tabular}{lccccc}
\hline Group & MMP-9 & Bcl-2 & p-AMPK & p-mTOR & p-4ebp1 \\
\hline Control & $1.01 \pm 0.01$ & $1.00 \pm 0.01$ & $1.01 \pm 0.01$ & $1.01 \pm 0.01$ & $1.00 \pm 0.01$ \\
$20 \mu \mathrm{g} / \mathrm{mL}$ adiponectin & $0.67 \pm 0.04^{\mathrm{a}}$ & $0.63 \pm 0.08^{\mathrm{a}}$ & $1.76 \pm 0.10^{\mathrm{a}}$ & $0.47 \pm 0.02^{\mathrm{a}}$ & $0.11 \pm 0.01^{\mathrm{a}}$ \\
Adiponectin + AMPK inhibitor & $0.93 \pm 0.08^{\mathrm{ab}}$ & $0.92 \pm 0.07^{\mathrm{ab}}$ & $1.15 \pm 0.06^{\mathrm{ab}}$ & $1.18 \pm 0.04^{\mathrm{ab}}$ & $1.17 \pm 0.05^{\mathrm{ab}}$ \\
$F$ & 46.81 & 39.89 & 139.30 & 785.33 & 1440.44 \\
$P$-value & $<0.001$ & $<0.001$ & $<0.001$ & $<0.001$ & $<0.001$ \\
\hline
\end{tabular}

Values presented are mean \pm SD. ${ }^{a} P<0.05$, vs control; ${ }^{b} p<0.05$; vs the $20 \mu \mathrm{g} / \mathrm{mL}$ adiponectin group 
Adiponectin is the only adipose tissue factor with decreased levels in obese patients. Plasma adiponectin level is significantly and negatively correlated with endometrial cancer. Busch et al [8] reported that adiponectin level in abdominal adipose tissue may be an effective predictor of endometrial cancer. In this investigation, the impact of adiponectin on the biological behavior of endometrial cancer cells, and the associated mechanism, were studied in RL95-2 cells.

Continuous proliferation, invasion and metastasis are vital characteristics of cancers which also constitute crucial problems in cancer treatment at present [9]. In this study, CCK-8 assay, Transwell cell invasion and migration assay, and flow cytometry were used to determine proliferation, invasion, migration and apoptosis of cells in each group, while the expression levels of apoptosis-related protein Bcl-2 and migrationrelated protein MMP-9 were determined with western blot assay. The results showed that adiponectin enhanced apoptosis of RL95-2 cells and inhibited their proliferation, invasion and migration. These results are similar to the findings reported by Takagi et al [10].

It is known that AMPK is a heterotrimeric protein involved in a variety of chronic diseases, including obesity and inflammation. Studies have shown that when AMPK is inactivated, tumor cells reduce the activity of p53, increase the activity of hypoxia-inducing factors, and improve aerobic glycolysis, thereby promoting tumor cell growth and proliferation [11]. Some scholars have reported that AMPK mediates the effects of adiponectin on a variety of cells [12]. Adiponectin affects the proliferation and apoptosis of breast cancer cells by activating the phosphorylation of AMPK [13]. The serine/threonine protein kinase, mTOR, is a downstream protein negatively regulated by AMPK. It integrates multiple signals and participates in gene transcription, lysosomal synthesis, protein translation, and regulation of cell growth and proliferation. Studies have found that mTOR is highly expressed in a variety of malignant tumor cells, and it may regulate translation by phosphorylating its downstream target protein 4EBP1 [14]. The results of this study showed that adiponectin stimulated AMPK phosphorylation and inhibited mTOR phosphorylation, while AMPK inhibitors blocked these effects. Thus, the AMPK/mTOR signal route may be involved in the pathogenesis of endometrial cancer.

\section{CONCLUSION}

Adiponectin promotes apoptosis of endometrial cancer cells and inhibits their proliferation, invasion and migration via AMPK/mTOR signaling pathway. Thus, adiponectin is a potential anti-tumor agent for the management of endometrial cancer.

\section{DECLARATIONS}

\section{Conflict of interest}

No conflict of interest is associated with this work.

\section{Contribution of authors}

We declare that this work was performed by the authors named in this article and all liabilities pertaining to claims relating to the content of this article will be borne by the authors. Dan Luo designed the study, supervised the data collection, and analyzed the data. $\mathrm{Li}$ Jin interpreted the data and prepared the manuscript for publication. Xiumei Feng supervised the data collection, analyzed the data and reviewed the draft of the manuscript.

\section{Open Access}

This is an Open Access article that uses a funding model which does not charge readers or their institutions for access and distributed under the terms of the Creative Commons Attribution License (http://creativecommons.org/licenses/by/ 4.0) and the Budapest Open Access Initiative (http://www.budapestopenaccessinitiative.org/rea d), which permit unrestricted use, distribution, and reproduction in any medium, provided the original work is properly credited.

\section{REFERENCES}

1. Mardelle A, Delphine P, Lucia R, Jelle J, Georg H. An Ectopic Network of Transcription Factors Regulated by Hippo Signaling Drives Growth and Invasion of a Malignant Tumor Model. Curr Biol 2016; 26(16): 21012113.

2. William JG, Erling AH, Mari KH, Amaro TW, Helga BS. The genomic landscape and evolution of endometrial carcinoma progression and abdominopelvic metastasis. Nat Genet 2016; 48(8): 848-855.

3. McCampbell AS, Mittelstadt ML, Dere R, Kim S, Zhou L, Djordjevic B, Soliman PT, Zhang Q, Wei C, Hursting SD, et al. Loss of p27 Associated with Risk for Endometrial Carcinoma Arising in the Setting of Obesity. Curr Mol Med 2016; 16(3): 252-265.

4. Fabien $D$, Esther $D S$, Hadia $M$, Valérie $S$, Nelly $S B$, François V, Marie-Noëlle $D$. Adiponectin limits differentiation and trophoblast invasion in human 
endometrial cells. J Mol Endocrinol 2017; 59(3): 285297.

5. Qiulian L, Chao Z, Ruichao C, Hanzhen X, Fuman $Q$, Shaoyan L, Minfen Z, Fang $W, Y u W$, Xuan Z, et al. Disrupting MALAT1/miR-200c sponge decreases invasion and migration in endometrioid endometrial carcinoma. Cancer Lett 2016, 383(1): 28-40.

6. Stubert J, Gerber B. Current Issues in the Diagnosis and Treatment of Endometrial Carcinoma. Geburtshilfe Frauenheilkd 2016; 76(02): 170-175.

7. Sequeira M, Pain SJ, Brun V, Meikle A, Kenyon PR, Blair HT. Gestation-related gene expression and protein localization in endometrial tissue of Suffolk and Cheviot ewes at gestation Day 19, after transfer of Suffolk or Cheviot embryos. Theriogenol 2016; 86(6): 1557-1565.

8. Busch EL, Marta C, Jennifer $P$, Michael JD, Bernard AR, George LM, Immaculata DV. Adiponectin, Leptin, and Insulin-Pathway Receptors as Endometrial Cancer Subtyping Markers. Horm Cancer 2018; 9(1): 33-39.

9. Zhiguo $L$, Dianjun $W$, Chao $Y$, Honggang $S$, Tao $L$, Defeng $K$. Overexpression of long noncoding RNA, NEAT1 promotes cell proliferation, invasion and migration in endometrial endometrioid adenocarcinoma. Biomed Pharmacother 2016; 84(21): 244-251.
10. Kiyoshi T, Yasuhiro M, Sota T, Chiaki H, Mika W, Hironobu S, Kiyoshi I, Takashi S. Nucleobindin 2 (NUCB2) in human endometrial carcinoma: a potent prognostic factor associated with cell proliferation and migration. Endocr J 2016; 63(3): 287-299.

11. Zhao $L$, Shasha $Q$, Xingbo Z, Mingjiang $L$, Sentai $D$, Jiaju $L$, Hui Z. Metformin inhibits 17 $\beta$-estradiol-induced epithelial-to-mesenchymal transition via $\beta$ Klotho-related ERK1/2 signaling and AMPKa signaling in endometrial adenocarcinoma cells. Oncotarget 2016; 7(16): 2131521331.

12. Stavros K, Poornima H, John AT, Kevin PC. AMPKa Is Suppressed in Bladder Cancer through MacrophageMediated Mechanisms. Transl Oncol 2016; 9(6): 606616.

13. Rui W, Yajun C, Dongwei S, Boshen G, Xiaobo $H$, Xinyu Z, Zhijun P, Lingtao C, Yuelei C, Zhenzhen Y. Cpt1C regulated by AMPK promotes papillary thyroid carcinomas cells survival under metabolic stress conditions. J Cancer 2017; 8(18): 3675-3681.

14. Yunyun L, Zhongzu Z, Xiaojing Z, Ying L, Tangshu L, Zhenghua X, Qin Z. A dual PI3KJAKT/mTOR signaling inhibitor miR-99a suppresses endometrial carcinoma. Ame J Transl Res 2016; 8(2): 719-731. 